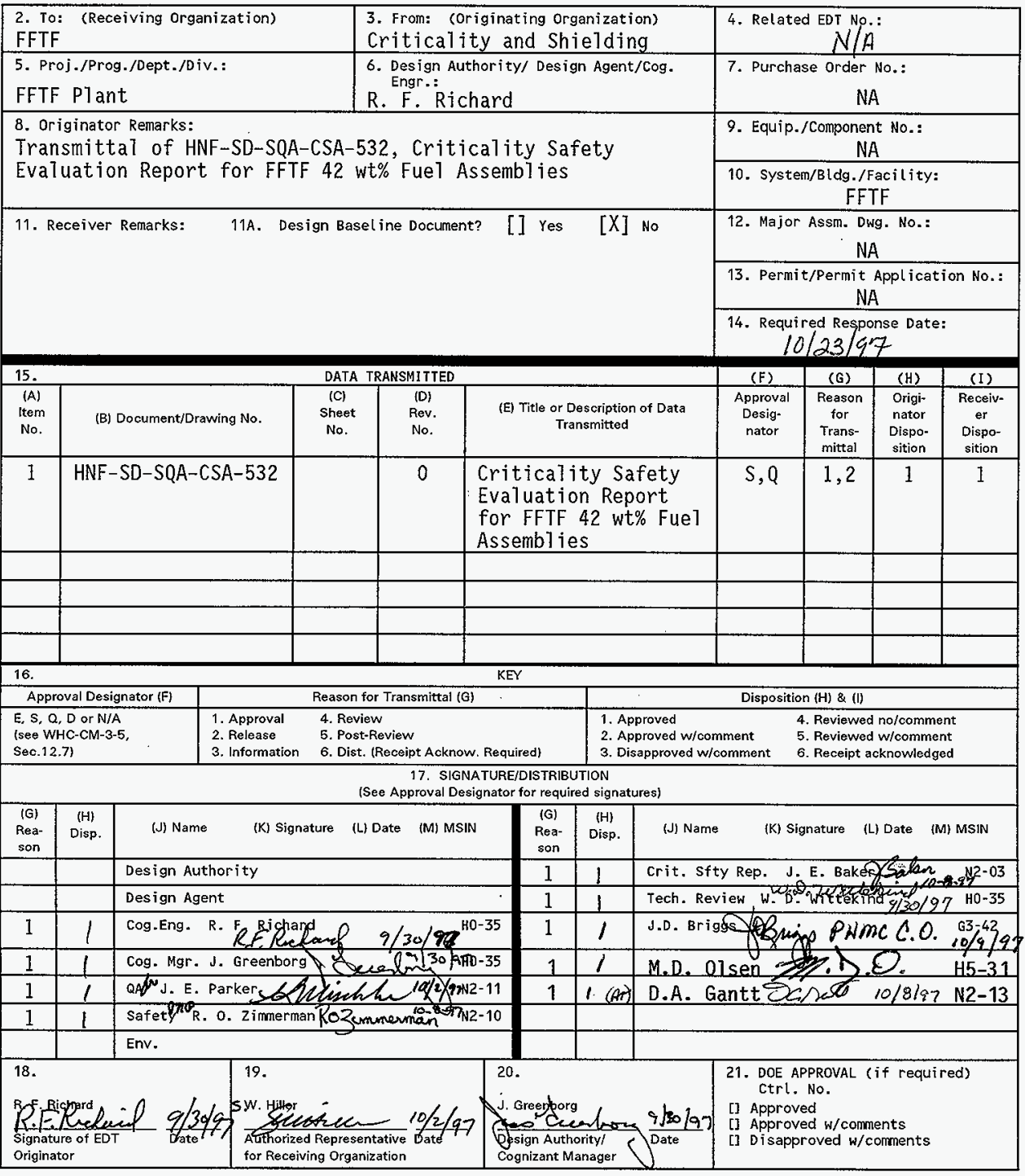

BD-7400-172-2 (05/96) GEF097 


\section{Criticality Safety Evaluation Report for FFTF $42 \%$ Fuel Assemblies}

R. F. Richard

Fluor Daniel Northwest, Inc., RichTand, WA 99352

U.S. Department of Energy Contract DE-AC06-96RL13200

EDT/ECN: 622979

UC: 533

Org Code: 403

B\&R Code: EX7003000

Charge Code: BE2600

Total Pages: $1925 \mathrm{c}$

Key Words: Minimum Critical Number, Criticality, FFTF, CCC, IDS, IEM, ISC, FSF

Abstract: This Criticality Safety Evaluation determines the minimum critical number for $42 \mathrm{wt} \%$ PuO FFTF fuel assemblies. Also addressed is an assessment of the criticality evaluation needs for IDS and FSF with respect to this fuel.

TRADEMARK DISCLAIMER. Reference herein to any specific commercial product, process, or service by trade name, trademark, manufacturer, or otherwise, does not necessarily constitute or imply its endorsement, recosmendation, or favoring by the United States Government or any agency thereof or its contractors or subcontractors.

Printed in the United States of America. To obtain copies of this document, contact: Document Control Services, P.0. Box 950, Mailstop H6-08, Richland WA 99352, Phone (509) 372-2420; Fax (509) 376-4989.

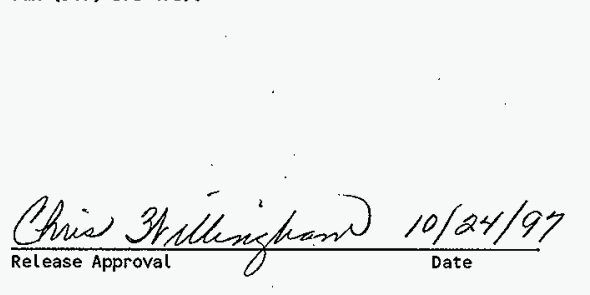

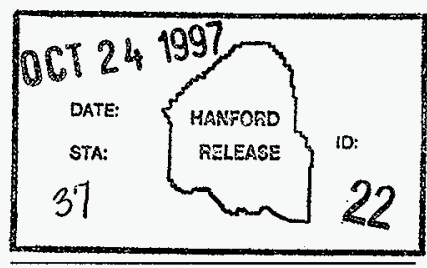

Release Stamp 
HNF-SD-SQA-CSA-532 Rev. 0

CSER 97-006

Title: Criticality Safety Evaluation Report for FFTF 42 wt\% Fuel Assemblies

Prepared by: Polit F Ruched Reviewed by: $\frac{2 \text { Carew D.2 Sithekind }}{\text { Engineer, Criticality and Shielding }}$ Date: 30 September 1997

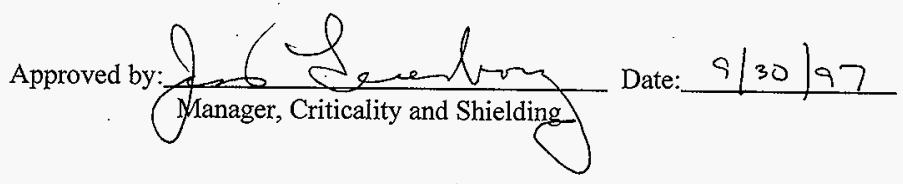

i 
HNF-SD-SQA-CSA-532 Rev. 0

\section{Contents}

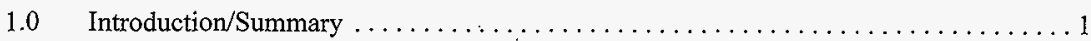

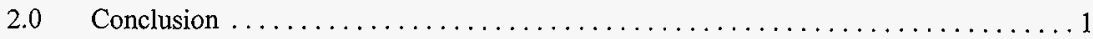

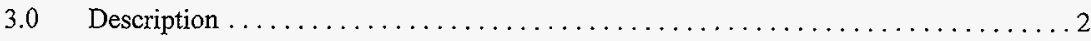

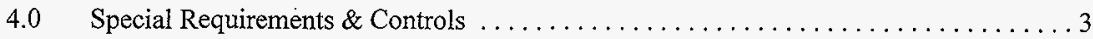

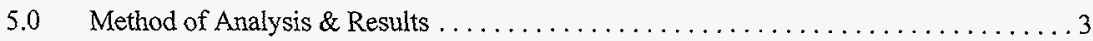

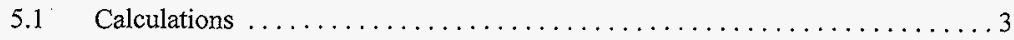

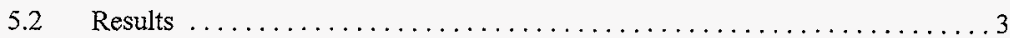

5.2.1 Minimum Critical Number in Water $\ldots \ldots \ldots \ldots \ldots \ldots \ldots \ldots$

5.2.2 Minimum Critical Number in Sodium $\ldots \ldots \ldots \ldots \ldots \ldots \ldots \ldots$

5.2.3 Minimum Critcal Number in Air $\ldots \ldots \ldots \ldots \ldots \ldots \ldots \ldots$

5.3 Assessment of $42 \mathrm{wt} \%$ Pu Fuel Assembly Storage in CCC/ISC . . . . . . . 8

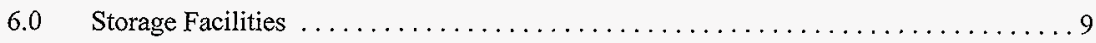

6.1 Interim Examination \& Maintenance Cell $\ldots \ldots \ldots \ldots \ldots \ldots$

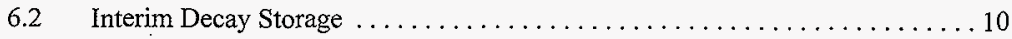

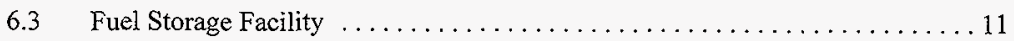

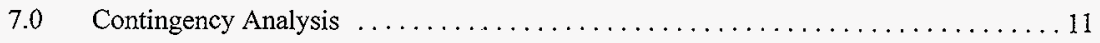

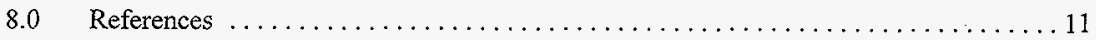

Appendix A Sample MONK6B Input Files $\ldots \ldots \ldots \ldots \ldots \ldots \ldots \ldots \ldots \ldots \ldots \ldots \ldots \ldots$

Appendix B Independent Review Comments and Checklist $\ldots \ldots \ldots \ldots \ldots \ldots \ldots$ B-1 
HNF-SD-SQA-CSA-532 Rev. 0

\subsection{Introduction/Summary}

An FFTF tritium/isotope production mission will require a new fuel supply. The reference design core will use a mixed oxide fuel nominally enriched to $40 \mathrm{wt} \% \mathrm{Pu}$. This enrichment is significantly higher than that of the standard Driver Fuel Assemblies used in past operations. Consequently, criticality safety for handling and storage of this fuel must be addressed. The purpose of this document is to begin the process by determining the minimum critical number for these new fuel assemblies in water, sodium and air. To conservatively bound the fuel for the reference design core, the analysis was done using $42 \mathrm{wt} \% \mathrm{Pu}\left(5.96 \mathrm{wt} \%{ }^{240} \mathrm{Pu}\right) \mathrm{O}_{2}$ . This analysis is preliminary and further work can be done to refine the results reported here. Analysis was initially done using $45 \mathrm{wt} \% \mathrm{PuO}_{2}$ fuel assemblies and are also reported. Additionally, a preliminary assessment is done concerning storage of these fuel assemblies in Iriterim Decay Storage (IDS), Fuel Storage Facility (FSF), and Core Component Containers/Interim Storage Casks (CCC/ISC).

\subsection{Conclusion}

For $42 \mathrm{wt} \% \mathrm{PuO}_{2}$ fuel assemblies in water the minimum critical number is greater than 3 and less than four, greater than 10 and less than 11 in sodium, and greater than 13 and less than 14 in air. The minimum critical number in sodium and air is based on a conservative model of the assembly arrays with close concrete reflection. Refinement of this analysis could be done in the future that may possibly increase the minimum critical number in sodium and air, if needed.

It is likely that at least six $42 \mathrm{wt} \%$ fuel assemblies can be safely stored in a CCC/ISC.

An assessment of existing IDS and FSF criticality documentation resulted in the conclusion that further analysis is required before $42 \mathrm{wt} \%$ fuel assemblies can be stored in either.

With $42 \mathrm{wt} \% \mathrm{PuO}_{2}$ fuel the number of fuel units in the IEM Cell shall not exceed 9. Individual pins are not allowed without further analysis. Floor grid structures must be in place when this fuel is present in the Cell. 


\section{HNF-SD-SQA-CSA-532 Rev.0}

\subsection{Description}

For this analysis the fuel assemblies were explicitly modeled with 217 pins. Assembly and pin dimensions used are those of a standard FFTF driver fuel assembly. Dimensions are provided in Table 1.

Table 1. Fuel Assembly Dimensions

\begin{tabular}{|c|c|}
\hline Dimension & in (cm) \\
\hline \hline cladding - inner diameter & $0.200(0.5080)$ \\
\hline cladding - outer diameter & $0.230(0.5840)$ \\
\hline duct - inner wall to wall & $4.335(11.0109)$ \\
\hline duct - outer wall to wall & $4.575(11.6205)$ \\
\hline
\end{tabular}

Analyses were done for both $42 \mathrm{wt} \% \mathrm{Pu}$ fuel and $45 \mathrm{wt} \% \mathrm{Pu}$ fuel. The isotopic distribution is from DOE/EIS-0229. Masses for both are given in Table 2.

Table 2. Fuel Masses (grams)

\begin{tabular}{|c|c|c|}
\hline nuclide & $42 \mathrm{wt} \% \mathrm{Pu}$ & $45 \mathrm{wt} \% \mathrm{Pu}$ \\
\hline${ }^{238} \mathrm{Pu}$ & 0.46 & 0 \\
\hline${ }^{239} \mathrm{Pu}$ & 12944.5 & 13943.3 \\
\hline${ }^{240} \mathrm{Pu}$ & 821.2 & 894.58 \\
\hline${ }^{241} \mathrm{Pu}$ & 5.83 & 75.61 \\
\hline${ }^{242} \mathrm{Pu}$ & 1.39 & 0 \\
\hline${ }^{241} \mathrm{Am}$ & 92.28 & 0 \\
\hline${ }^{235} \mathrm{U}$ & 41.4 & 39.6 \\
\hline${ }^{238} \mathrm{U}$ & 18979 & 18187 \\
\hline $\mathrm{O}$ & 4367 & 4413 \\
\hline
\end{tabular}




$$
\text { HNF-SD-SQA-CSA-532 Rev.0 }
$$

\subsection{Special Requirements and Controls}

The following analysis has determined that the minimum critical number for $42 \mathrm{wt} \%$ $\mathrm{PuO}_{2}$ fuel assemblies in water is between 3 and 4 . In sodium it is between 10 and 11, and, in air, between 13 and 14. Based on these results, and to assure the double contingency policy, these fuel assemblies are to be handled as a batch limit of 1 (max) assembly.

\subsection{Method of Analysis and Results}

\subsection{Calculations}

Calculations were done for unirradiated fuel assembly arrays in water, sodium and void (air). The fuel assembly ducts, pins and cladding were explicitly modeled. For most calculations the fuel assembly was modeled as a hexagon. A square fuel assembly model was used when there was no spacing between the assemblies allowing for close concrete reflection. For both the hexagonal model and square model the fuel pin pitch is 0.286 in. The modeling includes 12 inches of ordinary concrete reflection surrounding the array. Using ordinary concrete rather than high density concrete has no significant affect on $\mathrm{k}_{\text {eff }}$. A parametric evaluation was done by varying the moderator density and fuel assembly spacing. All calculations were done with MONK6B (UKAEA 1988). MONK6B has been validated for Pu systems. Accounting for margins of safety and biasing, a calculated $k_{\text {eff }}$ of 0.935 is considered to be critical (Macklin 1991, Miller 1994).

\subsection{Results}

\subsubsection{MCN in Water}

Results of the analysis show that, in water the minimum critical number of fuel assemblies is greater than 3 and less than 4 . This is true for fuel enrichment of either $42 \mathrm{wt} \% \mathrm{Pu}$ or $45 \mathrm{wt} \% \mathrm{Pu}$. With four assemblies $\mathrm{k}_{\mathrm{eff}}$ is over the 0.935 calculational limit and under 0.935 for three assemblies. The difference in $\mathrm{k}_{\text {eff }}$ for 3 assemblies between the two enrichments is 0.0176 . Table 3 presents the $\mathrm{k}_{\text {eff }}$ 's for 2,3 and 4 fuel assemblies for both enrichments. For these cases the assemblies are separated by $0.75 \mathrm{in}$. Also included in this, and the following tables, are the MONK6B file names for each calculation. 
HNF-SD-SQA-CSA-532 Rev. 0

Table 3. Assemblies in Water, Spacing $=0.75$ in.

\begin{tabular}{|c|c|c|c|c|c|c|}
\hline \multirow{2}{*}{$\begin{array}{c}\text { Number of } \\
\text { Assemblies }\end{array}$} & \multicolumn{3}{|c|}{$42 \mathrm{wt} \% \mathrm{Pu}$} & \multicolumn{3}{|c|}{$45 \mathrm{wt} \% \mathrm{Pu}$} \\
\cline { 2 - 7 } & $\mathrm{k}_{\text {eff }}$ & $\sigma_{\mathrm{c}}$ & file & $\mathrm{k}_{\mathrm{eff}}$ & $\sigma_{\mathrm{c}}$ & file \\
\hline 4 & 0.9413 & 0.0030 & $\mathrm{mcn} 42 \mathrm{cw}$ & 0.9687 & 0.0031 & $\mathrm{mcn} 45 \mathrm{cw}$ \\
\hline 3 & 0.8753 & 0.0029 & $\mathrm{mcn} 42 \mathrm{bw}$ & 0.8929 & 0.0030 & $\mathrm{mcn} 45 \mathrm{bw}$ \\
\hline 2 & 0.7571 & 0.0028 & $\mathrm{mcn} 42 \mathrm{mw}$ & 0.7892 & 0.0030 & $\mathrm{mcn} 45 \mathrm{mw}$ \\
\hline
\end{tabular}

Table 4 shows the affect of varying the distance between three fuel assemblies. The $\mathrm{k}_{\text {eff }}$ change as the assembly spacing goes from $0.39 \mathrm{in}$. to $0.75 \mathrm{in}$. is within the calculated uncertainty. The affect on $\mathrm{k}_{\text {eff }}$ as spacing decreases below $0.39 \mathrm{in}$. is not expected to be significant. As the assemblies move farther apart $k_{\text {eff }}$ goes down. The results presented here are for the assemblies oriented flat-to-flat. Rotating the assemblies to a vertex-to-vertex orientation has no significant affect on $k_{\text {efr. }}$. The calculations were done with ordinary concrete reflection. Substitution of the ordinary concrete with high density concrete had an insignificant affect on $\mathrm{k}_{\mathrm{eff}}$.

Table 4. Assemblies (3) in Water, Increasing Spacing

\begin{tabular}{|c|c|c|c|c|c|c||}
\hline \multirow{2}{*}{ Spacing (in.) } & \multicolumn{3}{|c|}{$42 \mathrm{wt} \% \mathrm{Pu}$} & \multicolumn{3}{c||}{$45 \mathrm{wt} \% \mathrm{Pu}$} \\
\cline { 2 - 7 } & $\mathrm{k}_{\text {eff }}$ & $\sigma_{\mathrm{c}}$ & file & $\mathrm{k}_{\text {eff }}$ & $\sigma_{\mathrm{c}}$ & file \\
\hline 0.39 & 0.8760 & 0.0030 & men $42 \mathrm{dw}$ & 0.8927 & 0.0029 & $\mathrm{mcn} 45 \mathrm{dw}$ \\
\hline 0.75 & 0.8753 & 0.0029 & mcn42bw & 0.8929 & 0.0030 & $\mathrm{mcn} 45 \mathrm{bw}$ \\
\hline 1.97 & 0.8134 & 0.0028 & men42kw & 0.8268 & 0.0028 & $\mathrm{mcn} 45 \mathrm{kw}$ \\
\hline 3.94 & 0.6917 & 0.0027 & $\mathrm{mcn} 42 \mathrm{lw}$ & 0.7141 & 0.0028 & $\mathrm{mcn} 451 \mathrm{w}$ \\
\hline
\end{tabular}

Table 5 shows the affect of reducing the water density around three fuel assemblies. For all cases, assembly spacing is $0.75 \mathrm{in}$. As the water density is reduced, $\mathrm{k}_{\mathrm{eff}}$ decreases. 
HNF-SD-SQA-CSA-532 Rev. 0

Table 5. Decreasing Water Density

\begin{tabular}{||c|c|c|c|c|c|c||}
\hline \hline \multirow{2}{*}{$\begin{array}{l}\text { Water Density } \\
\text { fraction }\end{array}$} & \multicolumn{3}{|c|}{$42 \mathrm{wt} \% \mathrm{Pu}$} & \multicolumn{3}{|c|}{$45 \mathrm{wt} \% \mathrm{Pu}$} \\
\cline { 2 - 7 } & $\mathrm{k}_{\text {eff }}$ & $\sigma_{\mathrm{c}}$ & file & $\mathrm{k}_{\text {eff }}$ & $\sigma_{\mathrm{c}}$ & file \\
\hline 1.0 & 0.8753 & 0.0029 & mcn42bw & 0.8927 & 0.0029 & men45dw \\
\hline 0.9 & 0.8555 & 0.0029 & men42nw & 0.8788 & 0.0031 & men45nw \\
\hline 0.8 & 0.8383 & 0.0030 & men42ow & 0.8603 & 0.0028 & men45ow \\
\hline 0.7 & 0.8206 & 0.0028 & men42pw & 0.8386 & 0.0031 & men45pw \\
\hline 0.5 & 0.7569 & 0.0027 & men42qw & 0.7798 & 0.0028 & men45qw \\
\hline 0.3 & 0.6874 & 0.0026 & mcn42rw & 0.7121 & 0.0025 & mcn45rw \\
\hline 0.1 & 0.6020 & 0.0024 & men42sw & 0.6244 & 0.0025 & men45sw \\
\hline dry & 0.5678 & 0.0022 & men42tw & 0.5955 & 0.0024 & men45tw \\
\hline \hline
\end{tabular}

\subsubsection{MCN in Sodium}

In sodium, the minimum critical number of $42 \mathrm{wt} \%$ fuel assemblies is greater than 10 and less than 11 (Table 8). Results are presented in Table 6 for $42 \mathrm{wt} \%$ and $45 \mathrm{wt} \%$ fuel with 0.75 in. spacing between assemblies.

Table 6. Assemblies in Sodium

\begin{tabular}{||c|c|c|c|c|c|c||}
\hline \multirow{2}{*}{$\begin{array}{c}\text { Number of } \\
\text { Assemblies }\end{array}$} & \multicolumn{3}{|c|}{$42 \mathrm{wt} \% \mathrm{Pu}$} & \multicolumn{3}{|c|}{$45 \mathrm{wt} \% \mathrm{Pu}$} \\
\cline { 2 - 7 } & $\mathrm{k}_{\mathrm{eff}}$ & $\sigma_{\mathrm{c}}$ & file & $\mathrm{k}_{\text {eff }}$ & $\sigma_{\mathrm{c}}$ & $\sigma_{\mathrm{c}}$ \\
\hline 16 & - & - & - & 1.0464 & 0.0031 & mcn45as \\
\hline 14 & 0.9653 & 0.0028 & mcn42cs & - & - & - \\
\hline 13 & 0.9368 & 0.0028 & mcn42ds & - & - & - \\
\hline 12 & 0.9264 & 0.0028 & mcn42bs & 0.9702 & 0.0029 & mcn45bs \\
\hline 11 & 0.8912 & 0.0027 & mcn42es & 0.9300 & 0.0028 & mcn45es \\
\hline 10 & - & - & - & 0.9036 & 0.0027 & mcn45cs \\
\hline 8 & - & - & - & 0.8204 & 0.0025 & men45ds \\
\hline \hline
\end{tabular}


HNF -SD-SOA-CSA-532 Rev. 0

The effect of changing the spacing between twelve $42 \mathrm{wt} \%$ fuel assemblies is presented in Table 7. With decreased spacing $k_{\text {eff }}$ increases and with increased spacing $k_{\text {eff }}$ decreases.

Table 7. Assembly (12) Spacing vs $k_{\text {eff }}$

\begin{tabular}{|c|c|c|c|}
\hline Spacing (in.) & $\mathrm{k}_{\text {eff }}$ & $\sigma_{\mathrm{c}}$ & file \\
\hline 0.0 & 0.9616 & 0.0028 & $\mathrm{sq} 3 \times 4 \mathrm{~s}$ \\
\hline 0.75 & 0.9264 & 0.0028 & men42bs \\
\hline 1.97 & 0.8380 & 0.0026 & mcn42ls \\
\hline 3.94 & 0.7437 & 0.0026 & mcn42ms \\
\hline
\end{tabular}

Table 8 presents the results with no spacing between the $42 \mathrm{wt} \%$ assemblies. The $\mathrm{k}_{\text {eff }}$ limit of 0.935 occurs between 10 and 11 assemblies. For these calculations the assembies were modeled as squares rather the hexagons. This allowed for closer concrete reflection around the assembly array.

Table 8. Assemblies in Sodium, No Spacing

\begin{tabular}{|c|c|c|c|}
\hline $\begin{array}{c}\text { Number of } \\
\text { Assemblies }\end{array}$ & $k_{\text {eff }}$ & $\sigma_{\mathrm{c}}$ & file \\
\hline 12 & 0.9616 & 0.0028 & $\mathrm{sq} 3 \times 4 \mathrm{~s}$ \\
\hline 11 & 0.9356 & 0.0028 & $\mathrm{sq} 11 \mathrm{~s}$ \\
\hline 10 & 0.8991 & 0.0027 & $\mathrm{sq} 10 \mathrm{~s}$ \\
\hline
\end{tabular}

As the sodium density is reduced $k_{\text {eff }}$ goes down. The results are presented in Table 9 for both enrichments and $0.75 \mathrm{in.} \mathrm{spacing.}$ 
HNF-SD-SQA-CSA-532 Rev. 0

Table 9. Decreasing Sodium Density

\begin{tabular}{||c|c|c|c|c|c|c||}
\hline \multirow{2}{*}{$\begin{array}{c}\text { Sodium Density } \\
\text { Fraction }\end{array}$} & \multicolumn{3}{|c|}{$42 \mathrm{wt} \% \mathrm{Pu}(12$ assemblies) } & \multicolumn{3}{|c|}{$45 \mathrm{wt} \% \mathrm{Pu}$ (11 assemblies) } \\
\cline { 2 - 7 } & $\mathrm{k}_{\text {eff }}$ & $\sigma_{\mathrm{c}}$ & file & $\mathrm{k}_{\text {eff }}$ & $\sigma_{\mathrm{c}}$ & file \\
\hline 1.0 & 0.9264 & 0.0028 & men42bs & 0.9300 & 0.0028 & mcn45es \\
\hline 0.9 & 0.9236 & 0.0027 & mcn42gs & 0.9294 & 0.0028 & mcn45gs \\
\hline 0.7 & 0.9176 & 0.0027 & mcn42hs & 0.9149 & 0.0027 & men45hs \\
\hline 0.5 & 0.9014 & 0.0027 & mcn42is & 0.9032 & 0.0027 & mcn45is \\
\hline
\end{tabular}

\subsubsection{MCN in Air}

In air the minimum critical number of assemblies is greater than 13 and less than 14 for $42 \mathrm{wt} \%$ fuel assemblies (Table 12). Results for both $42 \mathrm{wt} \%$ and $45 \mathrm{wt} \%$ fuel with $0.75 \mathrm{in}$. spacing are presented in Table 10.

Table 10. Assemblies in Air

\begin{tabular}{|c|c|c|c|c|c|c||}
\hline \multirow{2}{*}{$\begin{array}{c}\text { Number of } \\
\text { Assemblies }\end{array}$} & \multicolumn{3}{|c|}{$42 \mathrm{wt} \% \mathrm{Pu}$} & \multicolumn{3}{c|}{$45 \mathrm{wt} \% \mathrm{Pu}$} \\
\cline { 2 - 7 } & $\mathrm{k}_{\text {eff }}$ & $\sigma_{\mathrm{c}}$ & file & $\mathrm{k}_{\text {eff }}$ & $\sigma_{\mathrm{c}}$ & file \\
\hline 16 & 0.9369 & 0.0027 & $\mathrm{men} 42 \mathrm{ad}$ & 0.9721 & 0.0027 & $\mathrm{mcn} 45 \mathrm{ad}$ \\
\hline 15 & 0.9078 & 0.0027 & $\mathrm{mcn} 42 \mathrm{hd}$ & - & - & - \\
\hline 14 & 0.8879 & 0.0026 & $\mathrm{mcn} 42 \mathrm{~cd}$ & 0.9274 & 0.0027 & $\mathrm{mcn} 45 \mathrm{~cd}$ \\
\hline 12 & - & - & - & 0.9017 & 0.0027 & men45bd \\
\hline
\end{tabular}

The effect on $\mathrm{k}_{\mathrm{eff}}$ of changing the spacing between 15 fuel assemblies in air is shown in Table 11 . 
HNF-SD-SQA-CSA-532 Rev.0

Table 11. Assembly Spacing vs $\mathrm{k}_{\text {eff }}$ in Air

\begin{tabular}{|c|c|c|c|}
\hline \hline \multirow{2}{*}{ Spacing (in.) } & \multicolumn{3}{|c|}{$42 \mathrm{wt} \% \mathrm{Pu}(15$ assemblies) } \\
\cline { 2 - 4 } & $\mathrm{k}_{\mathrm{eff}}$ & $\sigma_{\mathrm{c}}$ & file \\
\hline 0.0 & 0.9749 & 0.0027 & sq15d \\
\hline 0.75 & 0.9078 & 0.0027 & men42hd \\
\hline 1.97 & 0.7775 & 0.0026 & men42ed \\
\hline 3.94 & 0.7055 & 0.0025 & men42fd \\
\hline
\end{tabular}

$\mathrm{K}_{\text {eff }}$ increases as the spacing between assemblies decreases. Table 12 presents the results for no spacing between the $42 \mathrm{wt} \%$ fuel assemblies in air.

Table 12. No Spacing Between $42 \mathrm{Wt} \%$ Assemblies

\begin{tabular}{|c|c|c|c||}
\hline $\begin{array}{c}\text { Number of } \\
\text { assemblies }\end{array}$ & $\mathrm{k}_{\text {eff }}$ & $\sigma_{\mathrm{c}}$ & file \\
\hline 16 & 1.0125 & 0.0028 & $\mathrm{sq} 4 \times 4 \mathrm{~d}$ \\
\hline 15 & 0.9749 & 0.0027 & $\mathrm{sq15d}$ \\
\hline 14 & 0.9382 & 0.0027 & $\mathrm{sq} 14 \mathrm{~d}$ \\
\hline 13 & 0.9101 & 0.0027 & sq13d \\
\hline
\end{tabular}

The maximum allowable $\mathrm{k}_{\text {eff }}, 0.935$, occurs between 13 and 14 assemblies. These results are conservative because the assemblies were modeled as squares rather than hexagons allowing for tighter concrete reflection.

\subsection{Assessment of $42 \mathrm{wt} \%$ Pu Fuel Assembly Storage in CCC/ISC}

All fuel assemblies will eventually be stored in CCC/ISCs. Much analysis has previously been performed pertaining to the storage of standard Series I and II FFTF Driver Fuel Assemblies (DFAs), pin containers and metal fuel in CCC/ISCs. To establish a preliminary estimate of the number of $42 \mathrm{wt} \%$ fuel assemblies that can be stored in a CCC/ISC, two calculations were performed. In one calculation six metal assemblies in a CCC/ISC are replaced 


$$
\text { HNF-SD-SQA-CSA-532 Rev.0 }
$$

with six $42 \mathrm{wt} \%$ fuel. In the second calculation in a CCC/ISC with five metal and two DFAs, the five metal assemblies are replaced with five $42 \mathrm{wt} \% \mathrm{Pu}$ assemblies. As for the metal assembly cases, no $42 \mathrm{wt} \%$ assemblies are in the center storage position when $42 \mathrm{wt} \%$ assemblies and DFAs are mixed. All cases are with intact fuel assemblies and are water moderated. The concrete of the ISC provides reflection. The results are presented in Table 13. Cases grm6c and grm5f are from a previous CCC/ISC analysis (Richard 1997).

Table 13. Fuel Assemblies in CCC/ISC

\begin{tabular}{|c|c|c|c|}
\hline CCC/ISC Loading & $\mathrm{k}_{\text {eff }}$ & $\sigma_{\mathrm{c}}$ & file \\
\hline $642 \mathrm{wt} \%$ assemblies & 0.8327 & 0.0028 & cccw6 \\
\hline 6 metal assemblies & 0.8537 & 0.0029 & grm6c \\
\hline $542 \mathrm{wt} \%+2$ DFAs & 0.8492 & 0.0029 & cccw5 \\
\hline 5 metal +2 DFAs & 0.8593 & 0.0029 & grm5f \\
\hline
\end{tabular}

These results show that a moderated $\mathrm{CCC} / \mathrm{ISC}$ with $42 \mathrm{wt} \% \mathrm{PuO}_{2}$ intact fuel assemblies has a lower $\mathrm{k}_{\mathrm{eff}}$ than a CCC/ISC with metal assemblies or one with five metal assemblies and two DFAs. This is a good indication that it is likely that at least six $42 \mathrm{wt} \% \mathrm{PuO}_{2}$ fuel assemblies could be stored in a CCC. However, further analysis is required to assess the effect of hot cell rot and to determine loading restrictions, if any.

\subsection{Storage Facilities}

A fuel assembly will reside in a variety of locations as it awaits insertion into the core and after discharge from the core. Each storage location has specific criticality requirements that must be met. This section addresses the current requirements of IDS and FSF and what will be necessary to allow storage of $42 \mathrm{wt} \% \mathrm{PuO}_{2}$ fuel assemblies.

\subsection{Interim Examination \& Maintenance Cell}

Based on the minimum critical mumber results of Section 5.2, the number of $42 \mathrm{wt} \%$ fuel units in the IEM Cell shall not exceed 9. Analyses of individual loose pins were not done.

This analysis does not address the situation of the $42 \mathrm{wt} \%$ fuel assemblies being in the Cell similtaneously with $31 \mathrm{wt} \%$ Driver Fuel assemblies or metal assemblies. The $31 \mathrm{wt} \%$ assemblies are clearly bounded by the $42 \mathrm{wt} \%$ assemblies and having both in the Cell at the same time may possibly be allowed with restrictions less stringent than those for the $42 \mathrm{wt} \%$ fuel. 


$$
\text { HNF-SD-SQA-CSA-532 Rev. } 0
$$

Further analysis is needed for conformation. Also, having both metal fuel and $42 \mathrm{wt} \%$ fuel in the Cell at the same time will require analysis before that is allowed.

\subsection{Interim Decay Storage}

The current IDS $\mathrm{k}_{\text {eff }}$ criticality limit is 0.90 . This limit allows the following fuel types to be loaded into the 112 storage positions in Rings B, C, D and E of the IDS array without restriction :

- MFF-2, MFF-3 and MFF-4;

- Assemblies of identical design to MFF-4 which contain uranium metal enriched to $34.0 \mathrm{wt} \%{ }^{235} \mathrm{U}$;

- DFAs containing mixed oxide enriched to $35.0 \mathrm{wt} \% \mathrm{PuO}_{2}$ with a ${ }^{240} \mathrm{Pu}$ content of 10.0 $w t \%$ (min.);

- Type A Assemblies;

- CRBR-3 and CRBR-5 assemblies after irradiation.

If DFAs are limited to $33.0 \mathrm{wt} \% \mathrm{PuO}_{2}$ with a ${ }^{240} \mathrm{Pu}$ content of $10.0 \mathrm{wt} \%$ (min.), the following assemblies may be stored in Rings B, C, D and E of IDS with a limit of 8:

- MFF-5 and MFF-6;

- Assemblies of identical design to MFF-2 which contain uranium metal enriched to $38.0 \mathrm{wt} \%{ }^{235} \mathrm{U}$;

- DFA's containing mixed oxide enriched to $39 \mathrm{wt} \% \mathrm{PuO}_{2}$ (max.) with a ${ }^{240} \mathrm{Pu}$ content of $10.0 \mathrm{wt} \%$ (min.);

- IFR-1.

Also, table 4 of the $A / B$ pin list allows MFF-8A in IDS .

It is apparent from the current restrictions that $42 \mathrm{wt} \% \mathrm{PuO}_{2}$ fuel assemblies can not, at this time, be stored in IDS. Existing analyses show that filling IDS with $11240 \mathrm{wt} \% \mathrm{PuO}_{2}$ with $11.5 \mathrm{wt} \%{ }^{240} \mathrm{Pu}$ fuel assemblies will result in a $\mathrm{k}_{\text {eff }}$ of 0.957 . Since the proposed FFTF Tritium/Isotope production mission requires a fuel enrichment of $40 \mathrm{wt} \% \mathrm{PuO}_{2}$ with $5.96 \mathrm{wt} \%$ ${ }^{240} \mathrm{Pu}$, an alternative IDS loading scheme will be required. Currently mixed oxide fuel up to 35.0 wt $\% \mathrm{PuO}_{2}$ with $\geq 10.0$ wt $\%{ }^{240} \mathrm{Pu}$ can be loaded into the storage postions of Rings $\mathrm{B}, \mathrm{C}, \mathrm{D}$ and $\mathrm{E}$ without restriction (provided there are no higher enriched assemblies in IDS, such as the MFF's). Limiting the number of $42 \mathrm{wt} \% \mathrm{PuO}_{2}$ fuel assemblies allowed in IDS sufficiently would result in $\mathrm{k}_{\text {eff }}$ less than 0.90 . Another alternative could be to add a neutron poison to IDS. It may be possible to take burnup credit for irradiated fuel. These options, or others, will require analysis to determine the best IDS loading for $42 \mathrm{wt} \%$ fuel assemblies without exceeding the $0.90 \mathrm{k}_{\text {eff }}$ limit. 


\section{HNF -SD-SQA-CSA-532 Rev.0}

\subsection{Fuel Storage Facility}

FSF was originally designed to store mixed oxide fuel enriched up to $29.3 \mathrm{wt} \% \mathrm{PuO}_{2}$. Currently up to $31 \mathrm{wt} \% \mathrm{PuO}_{2}$ fuel is allowed in FSF with the requirement that rows. 1,2 and 5 are sealed off and remain empty (Morford 1984). This assures that $k_{\text {eff }}$ will remain below 0.95 . As with IDS, with a new FFTF mission, FSF will be required to store the higher enriched fuel. To accomplish this could entail adding more neutron poison or restricting the $42 \mathrm{wt} \%$ fuel to specific rows. Burnup credit for irradiated fuel may be possible. An effort was initiated in the past, but not completed, to take credit for burnup in order to open the sealed rows (Morford 1993). The work was not completed and was based on fuel with enrichments less than $29.3 \mathrm{wt} \%$. Like IDS, analysis will be required to determine the best fuel loading scenario for FSF.

\subsection{Contingency Analysis}

This analysis has determined the minimum critical number of $42 \mathrm{wt} \%$ fuel assemblies in water, sodium and air. To assure the double contingency policy, these assemblies must be handled in batches that are less than half that required for a minimum critical number. This necessitates a batch limit of 1 ( $\max$ ) assembly.

\subsection{References}

DOE/EIS-0229, Storage and Disposition of Weapons-Usable Fissile Materials Final Programmatic Environmental Impact Statement, Volume III, December 1996.

Macklin, L. L., and E. M. Miller, 1991, CCVR 9I-001: MONK6A Pu Validation, WHC-SDSQA-CSWD-20015, Rev. 0, Westinghouse Hanford Company, Richland, Washington.

Miller, E. M., 1994, CCVR: MONK6B Pu Validation, WHC-SD-SQA-CSWD-20019, Rev. 0, Westinghouse Hanford Company, Richland, Washington.

Morford, R. J., Internal Memorandum to W. A. Dautel, "FSF, 31\% Pu Fuel Evaluation", May 7, 1984.

Morford, R. J., Internal Memorandum to J. W. Daughtry, "FFTF-FSF Reactivity Evaluation with Burned Fuel", Memorandum 22570-RJM-93-002, March 3, 1993.

Richard, R. F., Criticality Safety Evaluation for Long Term Storage of FFTF Fuel in Interim Storage Casks, WHC-SD-FF-CSER-004, Rev 1-B, May 1997. 


$$
\text { HNF-SD-SQA-CSA-532 Rev.0 }
$$

UKAEA, 1988, MONK6 A Monte Carlo Code for Criticality Calculations, ANSWERS

(MONK6) 2, AEEW R2248, Answers Business Centre, Winfrith Technology Centre, Dorchester, Dorset DT2 8DH, United Kingdom. 
HNF-SD-SQA-CSA-532 Rev.0

Appendix A

Sample MONK6B Input Files

A-1 


\section{HNF-SD-SQA-CSA-532 ReV. 0}

Following are MONK6B sample input files used in this analysis. First is the water moderated, three $\mathrm{PuO}_{2}$ fuel assembly case from Table 3 in section 5.2.1. The name of this input file is men $42 b w$.

All input files end with the extension .i, while all output files end with the extension .o or .prt. The MONK6B input and output files are saved on cfs. The $42 \mathrm{wt} \%$ files are saved as /w98142/mcn $42 /$ trit $42 . t a r . Z$. The $45 \mathrm{wt} \%$ files are saved as $/ \mathrm{w} 98142 / \mathrm{mcn} 45 /$ trit $45 . \operatorname{tar} . Z$.

* This MONK6B input describes 3 tritium core fuel assemblies

* These assemblies have 217 pins and the fuel is $42 \mathrm{wt} \% \mathrm{Pu}$

* The assemblies pins are modeled explicitly in a hexagonal duct.

*

* This is one of a series of calculations to determine the minimum

* critical number of these assemblies

$*$

* $1.88 \mathrm{~cm}$ separation exists between adjacent assemblies

$*$

* fuel assembly array is surrounded by 12 inches of reflecting concrete

*

* water moderation

$*$

FISSION

*

* Number of Materials Number of Nuclides 6 22

$*$

* Material compositions

NUCNAMES

* Keyword Nuclide Concentration (atoms $/ \mathrm{b}-\mathrm{cm}$ )

* unirradiated $45 \mathrm{wt} \%$ fuel

$\begin{array}{lll}\text { CONC } & \text { PU238 } & 0.0000003\end{array}$

PU239 0.008111

PU240 $\quad 0.000512$

PU241 $\quad 0.000004$

$\begin{array}{ll}\text { PU242 } & 0.000001\end{array}$

$\begin{array}{ll}\text { AM241 } & 0.000057\end{array}$

U235 0.000026

$\mathrm{U} 238 \quad 0.011942$

O $\quad 0.04088$

* Stainless Steel

$\begin{array}{lll}\text { CONC } & \text { MN } & 0.00155 \\ & \text { MO } & 0.00126\end{array}$ 


\section{HNF-SD-SQA-CSA-532 Rev. 0}

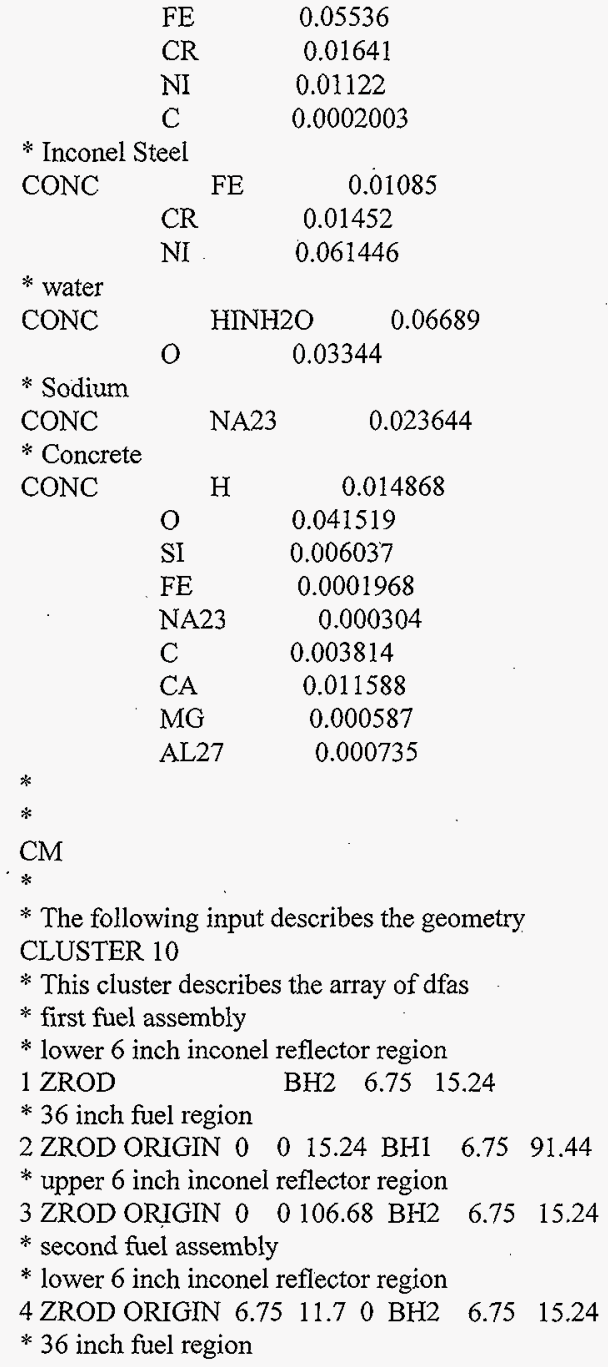


5 ZROD ORIGIN $6.75 \quad 11.715 .24$ BH1 6.7591 .44

* upper 6 inch inconel reflector region

6 ZROD ORIGIN $6.75 \quad 11.7 \quad 106.68$ BH2 $6.75 \quad 15.24$

* third fuel assembly

* lower 6 inch inconel reflector region

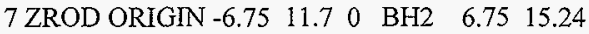

* 36 inch fuel region

8 ZROD ORIGIN $-6.75 \quad 11.715 .24$ BH1 6.7591 .44

* upper 6 inch inconel reflector region

9 ZROD ORIGIN -6.75 $11.7 \quad 106.68$ BH2 $6.75 \quad 15.24$

* cluster boundary

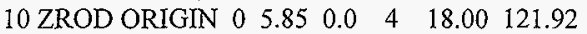

$*$

* cluster of assemblies within 12 inches concrete reflection

NEST 2

* 3 assemblies from part 1

$\begin{array}{lllllll}1 \text { ZROD ORIGIN } & 0 & 5.85 & 0 & \text { P1 } & 18.00 & 121.92\end{array}$

* 12 inches of concrete reflection

$\begin{array}{lllllll}2 \text { ZROD ORIGIN } & 0 & 5.85 & -30.48 & 6 & 38.5 & 182.88\end{array}$

*

$*$

* Hole 1: fuel region hole input

* hole type number of materials material numbers

TRIANGLE $\quad 3.124$

* lattice pitch inner radius outer radius

$\begin{array}{lll}0.72136 & 0.2540 & 0.2920\end{array}$

* duct dimensions

WRAP

* number of pins center to center to

* on side inner duct outer duct

$\begin{array}{lcc}9 & 5.50545 & 5.81025 \\ * \text { material inside } & \text { pin } & \begin{array}{c}\text { interstitual } \\ \text { material }\end{array} \\ * \quad \text { pins } & \text { material } & 4 \\ 1 & 2 & 4 \\ * \text { duct material } & \text { rest of space } \\ 2 & 4 \\ \text { * end of dfa fuel region input } \\ \text { * } \\ \text { * Hole 2: axial inconel reflector hole input } \\ \text { * hole type number of materials } \text { material numbers } \\ \text { TRIANGLE } & 3 & 234\end{array}$


* Iattice pitch inner radius outer radius 0.72136 0.2540 0.2920

* duct dimensions

WRAP

* number of pins

* on side

center to center to 9 inner duct outer duct

* materials inside

* pin 5.50545

2

pin

5.81025

material interstitual

* duct material 3 2 material 4

3 rest of space

* end of dfa axial inconel reflector region

*

* End of geometry input

*

* Superhistory option using 10 generations per superhistory

$*$ and nu nu multiplication factor $=1.0$

SUPERHIST $10 \quad 1.0$

* First stage Last stage Neutrons per stage Time limit Source $\begin{array}{lllll}-3 & 10 & 1000 & 180 & -1\end{array}$

$*$

* Starting Source

LINE 001600106

END

CODE 6

FSN*AC

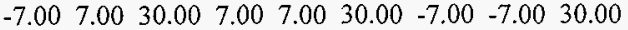

$-18.018 .0030 .0018 .0018 .0030 .00-18.00-18.0030 .00$

END 


\section{HNF-SD-SQA-CSA-532 Rev. 0}

The following MONK6B input file is an array of 11 fuel assemblies modeled as squares. The array has close concrete reflection. The file name is sq11s. The results of this case are presented in Table 8 of section 5.2.2.

* 11 DFAs (square model)

* in sodium

* 42 wt $\%$ fuel

* 12 inches concrete reflection

*

FISSION

* NUMBER OF MATERIAL 6 22

NUMBER OF NUCLIDES

NUCNAMES

* KEY WORD

* FUEL PIN

NUCLIDE CONCENTRATION(\# DENSITY)

CONC

\begin{tabular}{lc}
\multicolumn{1}{r}{ PU238 } & 0.00000 \\
PU239 & 0.008111 \\
PU240 & 0.000512 \\
PU241 & 0.000004 \\
PU242 & 0.000001 \\
U235 & 0.000026 \\
U238 & 0.011942 \\
AM241 & 0.000057 \\
O & 0.04088
\end{tabular}

* STAINLESS STEEL CONC

MN

$\begin{array}{ll}\text { MO } & 0.00126 \\ \text { FE } & 0.05536 \\ \text { CR } & 0.01641 \\ \text { NI } & 0.01122 \\ \text { C } & 0.0002003\end{array}$

* CARBON STEEL

$\begin{array}{llll}\text { CONC } & & \text { FE } & 0.083491 \\ & C & & 0.003921\end{array}$

* INCONEL STEEL

$\begin{array}{lcc}\text { CONC } & \text { FE } & 0.01085 \\ & \text { CR } & 0.01452 \\ & \text { NI } & 0.061446 \\ * \text { CONCRETE(210\#/cf) } & \\ \text { CONC } & \text { H } & 0.0063 \\ & \text { O } & 0.04046\end{array}$




\section{HNF-SD-SQA-CSA-532 Rev. 0}

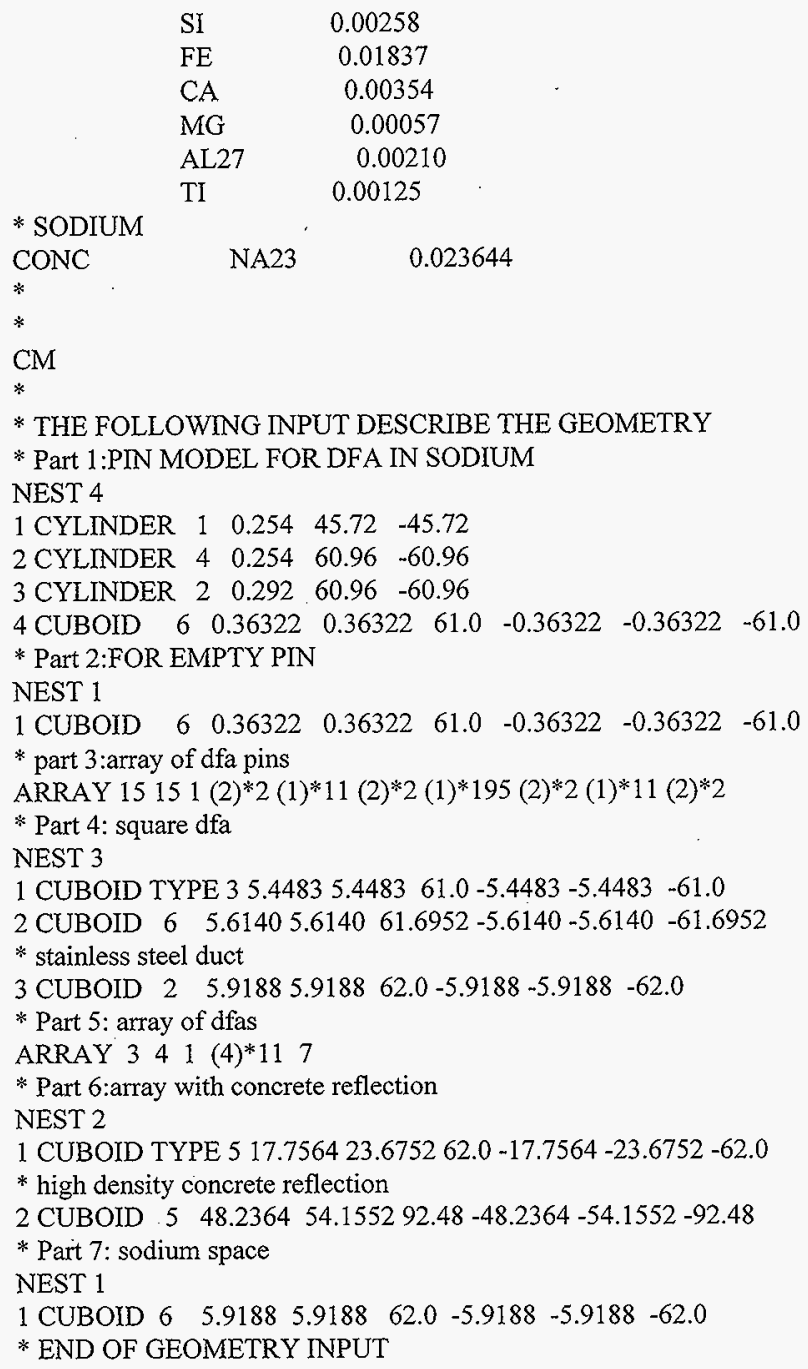


HNF-SD-SQA-CSA-532 Rev. 0

SUPERHIST $10 \quad 1.0$

* First stage last stage neUt per stage time lim source $\begin{array}{lllll}-3 & 10 & 1000 & 240 & -1\end{array}$

* STARTING SOURCE

MULTIFISS

STD

REGION 1 IN PART $6 /$

END

* SCAN PICTURE INPUT

CODE 6

FSCIRN

$\begin{array}{lllllllll}-6.0 & 6.0 & 0.0 & 6.0 & 6.0 & 0.0 & -6.0 & -6.0 & 0.0\end{array}$

$\begin{array}{lllllllll}-6.0 & 6.0 & 50.0 & 6.0 & 6.0 & 50.0 & -6.0 & -6.0 & 50.0\end{array}$

$\begin{array}{lllllllll}-32.0 & 32.0 & 0.0 & 32.0 & 32.0 & 0.0 & -32.0 & -32.0 & 0.0\end{array}$

END 
HNF-SD-SQA-CSA-532 Rev. 0

\section{Appendix B}

Independent Review Comments and Checklist

B-I 
HNF -SD-SQA-CSA-532 Rev. 0

CHECKLIST FOR INDEPENDENT TECHNICAL REVIEW

DOCUMENT REVIEWED

NUMBER: HNF-SD-SQA-CSA-532 Rev.0

TITLE: Criticality Safety Evaluation Report for FFTF 42 wt\% Fuel Assemblies

Reviewer(s) WAPREN D. WITTEKIND

I. Method(s) of Review

(L) Input data checked for accuracy

( ) Independent calculation performed

( ) Hand calculation

( ) Alternate computer code:

( ) Comparison to experiment or previous results

( ) Alternate method (define)

II. Checklist (either check or enter NA if not applied)

(4) Task completely defined

(2) Activity consistent with task specification

( $)$ Necessary assumptions explicitly stated and supported

(4) Resources properly identified and referenced

(L) Resource documentation appropriate for this application

( ) Input data explicitly stated

( $)$ Input data verified to be consistent with original source

(C) Geometric model adequate representation of actual geometry

(C) Material properties appropriate and reasonable

(L) Mathematical derivations checked including dimensional consistency

(L) Hand calculations checked for errors

( L) Assumptions explicitly stated and justified

(C) Computer software appropriate for task and used within range of validity

( $)$ Use of resource outside range of established validity is justified

(L) Software runstreams correct and consistent with results

(4) Software output consistent with input

(L) Results consistent with applicable previous experimental or analytical findings

( $)$ Results and conclusions address all points and are consistent with task requirements and/or established limits or criteria

( 4 Conclusions consistent with analytical results and established limits

(4) Uncertainty assesment appropriate and reasonable

( ) Other (define)

III. Comments:

IV. REVIEWER:Warrew D.Wittekind 30 September 1997 


\begin{tabular}{|c|c|c|c|c|c|}
\hline \multirow{2}{*}{$\begin{array}{l}\text { To } \\
\text { Distribution }\end{array}$} & \multirow{2}{*}{\multicolumn{3}{|c|}{$\begin{array}{l}\text { From } \\
\text { Criticality and Shielding }\end{array}$}} & \multicolumn{2}{|l|}{ Page 1 of 1} \\
\hline & & & & \multicolumn{2}{|c|}{$\begin{array}{l}\text { Date } \\
\text { September } 29,1997\end{array}$} \\
\hline \multicolumn{4}{|l|}{ Project Titje/Work Order } & \multicolumn{2}{|c|}{ EDT No. 622979} \\
\hline \multicolumn{4}{|c|}{$\begin{array}{l}\text { Criticality Safety Evaluation Report for FFTF } 42 \text { Wt\% Fuel } \\
\text { Assemblies }\end{array}$} & \multicolumn{2}{|l|}{ ECN No. } \\
\hline Name & MSIN & $\begin{array}{l}\text { Text } \\
\text { With All } \\
\text { Attach. }\end{array}$ & Text Only & $\begin{array}{l}\text { Attach./ } \\
\text { Appendix } \\
\text { Only }\end{array}$ & $\begin{array}{l}\text { EDT/ECN } \\
\text { Only }\end{array}$ \\
\hline
\end{tabular}

J. E. Baker

J. D. Briggs

W. A. Daute1

J. Greenborg

S. W. Hiller

D. L. Nielsen

J. N. Paglieri

J. E. Parker

P. R. Prevo

R. F. Richard

P. L. Scott

W. D. Wittekind

R. 0. Zimmerman

Central Files $(1+$ original)

$O S T$ (2) $D P C$

Station 22 (EDT, SD Cover only)
N2-57

G3-42 $X$

N2-13 $X$

HO-35 X

N2-02 $X$

N2-53 $X$

N2-57 $X$

N2-11 $X$

N2-57 X

H0-35 $\quad X$

N2-02 $X$

H0-35 $X$

N2-57 $X$

A3-88 $X$

G3- $11 A 3-94 X$

N2-12 